\title{
EXPLORING LEXICAL AND METRICAL STRESS IN MAYA ANGELOU'S POEM ENTITLED 'STILL I RISE': A PHONOLOGICAL ANALYSIS PERSPECTIVE
}

\author{
Putri Khumaeroh ${ }^{1}$ \\ Syahfitri Purnama ${ }^{2}$ \\ Universitas Indraprasta PGRI \\ e-mail: pkhumaeroh@yahoo.com ${ }^{1}$ \\ e-mail: syahfitripurnama@gmail.com ${ }^{2}$
}

\begin{abstract}
This study deals with phonological analysis, which focuses on analyzing lexical and metrical stress in Maya Angelou's poem entitled 'Still I Rise.' This study explores the lexical stress and metrical stress used in Angelou's poem, which answers the research questions. This method is the qualitative method which means the data was written text. The writer intends to determine what lexical stress (primary and secondary stress) and metrical stress (iamb, trochee, and dactyl) are in the poem text. This research showed that lexical stress, namely primary stress with total numbers, is 43 items, and secondary stress with total numbers is three items. Also, there are metrical stresses, including iamb with nine items, trochee 27 items, and dactyl seven items.
\end{abstract}

Keywords: lexical stress, metrical stress, phonological analysis

\begin{abstract}
Abstrak: Penelitian ini berkaitan dengan analisis fonologis yang berfokus pada analisis tekanan leksikal dan metrik dalam sebuah puisi karya Maya Angelou yang berjudul Still I Rise. Tujuan dari penelitian ini adalah untdiubah lan....uk mengeksplorasi tekanan leksikal dan metrik yang digunakan dalam puisi karya Angelou yang menjawab rumusan penelitian. Metode dalam penelitian ini menggunakan metode kualitatif yang mana dituangkan dalam sebuah kata. Penulis bermaksud untuk mencari tahu apa saja tekanan leksikal (tekanan primer dan sekunder) dan tekanan metrik (Iamb, Trochee and dactyl) yang terdapat di dalam teks puisi. Hasil penelitian ini menunjukan bahwa, terdapat tekanan leksikal, yaitu tekanan primer dengan total 43 item, dan untuk tekanan sekunder dengan total 3 item. Selain itu, terdapat tekanan metrik termasuk iamb dengan jumlah total 9 item, trochee dengan jumlah total 27 item dan dactyl dengan jumlah total 7 item.
\end{abstract}

Kata kunci: tekanan leksikal, tekanan metrik, analisis fonologis

\section{Introduction}

This study investigates lexical and metrical stress in Maya Angelo's poem text entitled "Still I Rise." This study proposes to catch how the speaker's lexical and metrical stress can boost new insight of EFL on speaking class. It captures two main principles of lexical stress: primary and secondary stress and three types of metrical stress: iamb, trochee, and dactyl in the phonological analysis perspective, which concerns the study of the sound. This study analyses how stress exists within the poem. Burdorf and Schallafer (as cited in Zettelman \& Rubik, 2005, p. 24) stated that a poem is a composition written for human voice performance. In the speaking area, proper pronunciation is essential to catch what the speaker meant. When the speaker pronounces some words in any situation, such as dialogue or monologue, in correct stressing, it will be very helpful the listener to catch the meaning that the speaker intends to. According to Hirst \& Di Cristo (1998), stress is the mark of emphasis given to a sound or syllable in spoken language. It means that the speaker emphasizes the syllable, which gets a prominence 
syllable in a word. When the speaker pronounces or says something with the right mark of prominence syllable, it easily makes the listener understand what the speaker meant.

In this case, the researcher tries to analyze lexical and metrical stress in the poem text entitled "Still I Rise." Metzeltin stated that he looked at the poem from the perspective of evolutionary anthropology and speculated upon the links between ritual and textuality (as cited in Zettelman \& Rubik, 2005, p. 15). As the researcher said before, the speaker's stress is significant to take the reader's attention. It is supported by Hopkins (1994, p.6) said that when reader's minds are filled with the poet's imaginings, they are transported out of their everyday. Besides the poet's stress, which takes the reader's attention, the poem's lyric will also affect the readers, as Vendler (1997, p.xiii) said that lyric is meant to give pleasure imaginative, linguistic, intellectual, and moral. If one has not enjoyed a poem and been moved by it, one has not experienced it as an artwork.

From the statement above, it can be concluded that stress and lyric in the poem can affect the readers where the poem is one form of communication activity using a unique style. A good poem is a word address that can be understood very well by the listener. When the speaker uses lexical and metrical stress in the reading poem, it gets the greatest pronunciation and expression in conveying the poem's meaning.

Goldsmith, Riggle, \& Yu (2011 p. 141) Lexical stress refers to increase prominence associated with a particular syllable or syllables in a prosodic domain. Moreover, Gut $(2009$, p. 84) stated that lexical stress is an abstract property of a syllable and part of the speakers' linguistic knowledge. It means that speakers of English know which syllable or syllables in a word are stressed. Besides, McMahon (2002, p.121) said that by leaving aside the question of predictability, we could certainly describe the position of stress on particular words accurately and using tree diagrams. In these diagrams, which form part of a theory called Metrical Phonology, each syllable is labeled either S or W: and because stress, as we saw above, is not an absolute but a relative property of syllables, these labels do not mean 'Strong' and 'Weak,' but 'Stronger than an adjacent $\mathrm{W}^{\prime}$ and 'Weaker than an adjacent S,' respectively. Charp (2013, p.164) stated that a metrical foot in English consists of a stressed syllable followed by zero or more unstressed syllables. The definitions above give a clear explanation of the concept of lexical and metrical stress. In other words, phonological analysis of lexical stress in this study is using the PRATT system. This study uses PRAAT system in analyzing the data of lexical stress that consists of primary and secondary stress and tree diagram model for the metrical stress.

This study uses a poem as a source of data. As the researcher knows that reading a poem is not as easy as reading a novel, it needs our expression and soul to get great listeners' attention. The most critical part in reading a poem is how the reader put the stress into the words and how the message conveyed well to the listener; the researcher sure that poem is one way to convey our feeling. It is supported by Robert \& Jacob (2006: 2), who said that poem is a composition that tells a story, dramatizes a situation, expresses emotion, analyzes and advocates ideas.

From the statement above, it can be concluded that poem is an essential communication activity in everyday life using a specific way of conveying its meaning. A good poem is a poem that can be addressed and can be understood very well by the listener or the reader. Besides that, there are many aspects to be conveyed in a poem, such as speakers' pronunciation, speakers' stressing, speakers' background knowledge, speakers' motivation, speakers' confidence. This study will investigate in-depth stress. In this study, the writer focuses on written text, especially poem text. The reason why the writer chooses poem text because it has an essential role in using stress correctly. The importance of studying lexical and metrical stress is to create a good and clear pronunciation and to make easily understand what information is delivered in it. It can also reduce confusion in understanding the texts because they will know how words get prominence in a syllable.

\section{Lexical Stress}

Lexical stress becomes an integral part of pronouncing words, sentences, and others. As Chun (2002, p.4) stated, stress is one way to convey particular effects, personality, attitude, and even meaning. Gut $(2009$, p.70) implied that stress refers to the prominence that certain syllables carry, making them stand out from the rest of the syllables in a word or sentence. Orion $(1976, p .17)$ stated that stress refers to the degree of force or loudness you give a syllable in a word or to a word or words in a phrase or sentence. Lexical stress is a feature of the word, a lexical abstraction or decontextualized from which becomes concrete realization only if the words get an accent in an utterance (Lira, 1998 p. 8). 
INFERENCE: Journal of English Language Teaching

Vol. 3, No. 1, April - July 2020

p-ISSN: 2615-8671

e-ISSN: 2615-868X

Furthermore, Cutler et al. (1997) said that stress patterns could help them distinguish between lexically ambiguous words such as to permit, which is usually stressed on the first syllable when it is a noun but stressed on the second syllable it is a verb. McMahon (2002, p. 120) said that some general rules do allow stress placement to be predicted in many English words. Here it is:

a. Noun Rule

Stress the penultimate syllable if heavy. If the penultimate syllable is light, stress the antepenult.

For example 1). a.' ro.ma

2). a.' gen.da

3). 'di.sci.pline

b. Verb Rule

Stress the final syllable if heavy. If the final syllable is light, stress the penultimate syllable.

For example 1). o.' bey

2). 'hu.rry

3). u.' surp

We can informally represent primary stress by placing a superscript diacritic ['] immediately before starting the appropriate syllable and secondary stress using the subscript diacritic [,]. These stress rules depend crucially on the syllable's weight; the syllable will be heavy if it has a branching rhyme, composed of either a long vowel or diphthong, with or without or a short vowel with a coda. A syllable with a short vowel and no coda will be light. As (a) English noun typically has stressed on the penultimate syllable, so long as that syllable is heavy, which is it in aroma (with a long [o:] vowel or diphthong [ov] depending on our accent, and an agenda, where the relevant vowel is short $[\varepsilon]$ but followed by a consonant, [n] this must be in the coda of syllable two rather than the onset of syllable three, since there are no * [nd] initial cluster in English. It will be supported by Gut $(2009$, p. 64) stated that phonemically long and short vowel in RP and GA, here it is the table that shows the phonemically long and short vowels in RP and GA:

Tabel 1

Phonemically long and short vowels in RP and GA

\begin{tabular}{|c|c|c|c|}
\hline \multicolumn{2}{|c|}{$\mathrm{RP}$} & \multicolumn{2}{|c|}{ GA } \\
\hline $\begin{array}{c}\text { Long } \\
\text { Vowels }\end{array}$ & $\begin{array}{c}\text { Short } \\
\text { Vowels }\end{array}$ & $\begin{array}{c}\text { Long } \\
\text { Vowels }\end{array}$ & $\begin{array}{c}\text { Short } \\
\text { Vowels }\end{array}$ \\
\hline i: & I & i: & I \\
\hline $\mathrm{u}$ : & U & $\mathrm{u}:$ & U \\
\hline ๑: & $\Lambda$ & ๑: & $\Lambda$ \\
\hline $\mathrm{a}:$ & $\nexists E$ & $\mathrm{a}:$ & $\nexists$ \\
\hline 3: & $\partial$ & 3: & $\partial$ \\
\hline & 9 & & э \\
\hline & $\mathrm{p}$ & & $\mathcal{B}$ \\
\hline
\end{tabular}

\section{Metrical Stress}

McMahon (2002, pp.125-126) said that feet could also be classified into types, three of which are shown in Figure 1. The Iambic Type (stress is in the second syllable), Structured W S, and Trochee (trochaic foot), where the stress is in the first syllable, contradicts the claim above that all feet begin with a stressed syllable and dactyl which the syllable starts with SWW. 


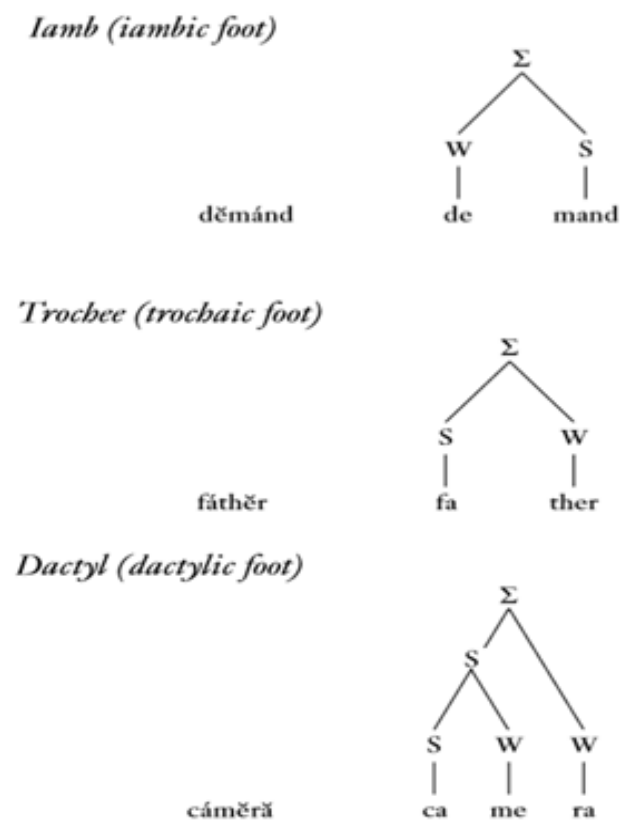

Figure 1. Types of Feet

Besides, to begin with, metrical trees (Liberman, 1975; Liberman and Prince, 1977; Hayes, 1984) in Sa'aida (2015, p. 64) represented the relational property of stress through sister nodes, each of which is labeled strong-weak (SW) or weak-strong (WS).

\section{Method}

The method of this research is qualitative research. Yin (2011, p. 8) stated that qualitative research could represent the participants' views and perspectives in a study. Capturing their perspectives may be a significant purpose of a qualitative study. Thus, the events and ideas emerging from qualitative research can represent the meanings given to real-life events by the people who live them, not the values, preconceptions, or meanings held by researchers. Also, Moleong (1993:3) stated that qualitative research is the type of research that does not include any calculation or enumeration because the data are produced in words. It means that qualitative data tend to be in the form of words than series of numbers. This study attempts to identify, classify, and describe the lexical and metrical stress taken from Angelou's poem entitled "Still I Rise." Moreover, Creswell (2009, p.4) stated that qualitative research is a means for exploring and understanding the meaning individuals or groups ascribe to a social or human problem. Then, Patton (1985) in Merriam (2009, p. 14) stated that qualitative research is an effort to understand situations in their uniqueness as part of a particular context and the interactions there.

In this research, the researcher adopted Ary et al. (2010, p. 486), who states that the research should be based on primary and secondary resources. The primary source which is taken in this study is a poem script from Maya Angelou entitled "Still I Rise." The researcher took from some linguistic books, journals, and reviews of some research while a secondary resource.

In conducting this research, the researcher takes these steps from the theory of Fraenkel, Wallen, \& Hyun (2011, pp. 429-431), they are (1) Identification of the phenomenon to be studied, (2) Identification of the participants in the study, (3) Data collection, (4) Data analysis, (5) Interpretations and conclusions. This research uses the researcher herself as the research instrument to collect, analyze, and identify the data because the discussion in this research is qualitative research. Moreover, 
INFERENCE: Journal of English Language Teaching

Vol. 3, No. 1, April - July 2020

p-ISSN: 2615-8671

e-ISSN: 2615-868X

qualitative research needs explanation from the researcher herself with supporting some reference books, journal articles.

\section{Findings and Discussion}

The discussion deals with the words which are analyzed based on the characteristics of it. McMahon's theory is adopted in this current research. Lexical stress is divided into primary and secondary stress. While metrical stress is divided into iambic foot, trochaic foot, and dactylic foot, they are divided into three types.

\section{Lexical Stress}

Here is the result of lexical stress that consists of primary and secondary stress found in Maya Angelou's poem entitled "Still I Rise," shown in Table 2.

Table 2.

The words of primary and secondary in Angelou's poem text

\begin{tabular}{|c|c|c|c|}
\hline No & $\begin{array}{c}\text { Lexical } \\
\text { Stress }\end{array}$ & Words & $\begin{array}{l}\text { Phonetic } \\
\text { Symbols }\end{array}$ \\
\hline 1 & \multirow{39}{*}{$\begin{array}{c}\text { Primary } \\
\text { Stress }\end{array}$} & History & ['histri] \\
\hline 2 & & Bitter & ['bitə(r)] \\
\hline 3 & & Twisted & ['twistid] \\
\hline 4 & & Very & ['Veri] \\
\hline 5 & & Sassiness & ['sæsi,nəs] \\
\hline 6 & & Upset & [, $\Lambda$ p'set] \\
\hline 7 & & Beset & [bI'set] \\
\hline 8 & & Because & [bI'kəz] \\
\hline 9 & & Pumping & ['p $\wedge$ mpin] \\
\hline 10 & & Living & ['livin] \\
\hline 11 & & Certainty & ['s3:tnti] \\
\hline 12 & & Springing & ['sprinin] \\
\hline 13 & & Broken & ['broukən] \\
\hline 14 & & Lowered & ['ləuəd] \\
\hline 15 & & Shoulders & 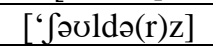 \\
\hline 16 & & Falling & ['fo:lin] \\
\hline 17 & & Teardrops & ['tiə(r)drop] \\
\hline 18 & & Weakened & [,wi:'keInd] \\
\hline 19 & & Soulful & ['səolful] \\
\hline 20 & & Haughtiness & ['ho:tinəs] \\
\hline 21 & & Offend & [ə'fend] \\
\hline 22 & & Awful & ['o:fl] \\
\hline 23 & & Because & [bI'kəz] \\
\hline 24 & & Digging & ['digin] \\
\hline 25 & & Hatefulness & ['heitfulnəs] \\
\hline 26 & & Sexiness & ['seksinəs] \\
\hline 27 & & Upset & [, $\Lambda$ p'set] \\
\hline 28 & & Surprise & [sə’praiz] \\
\hline 29 & & Diamonds & ['daiəmənd(z)] \\
\hline 30 & & Meeting & ['mi:tin] \\
\hline 31 & & History;s & ['hIstris] \\
\hline 32 & & Rooted & ['ru:təd] \\
\hline 33 & & Ocean & 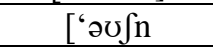 \\
\hline 34 & & Leaping & ['li:pIn \\
\hline 35 & & Welling & ['welın] \\
\hline 36 & & Swelling & ['swelin] \\
\hline 37 & & Living & ['li:vin] \\
\hline 38 & & Behind & [bI'haind] \\
\hline 39 & & Terror & {$\left[{ }^{\prime} \operatorname{ter}(\mathrm{r})\right]$} \\
\hline
\end{tabular}




\begin{tabular}{|c|c|c|c|}
\hline 40 & & Daybreak & ['derbrerk] \\
\hline 41 & & Wondrously & ['WAndrəsli] \\
\hline 42 & & Bringing & ['brinin] \\
\hline 43 & & Ancestors & ['ænsestərz] \\
\hline 1 & \multirow{3}{*}{$\begin{array}{c}\text { Secondary } \\
\text { Stress }\end{array}$} & Upset & [,ıp'set] \\
\hline 2 & & Sassiness & ['sæsi,nəs] \\
\hline 3 & & Weakened & [,wi:'kemd] \\
\hline
\end{tabular}

The data above shows that 43 items found in Angelou's poem will be analyzed in this research using the PRAAT system. Table 3 shows the result of lexical stress.

Table 3.

Lists of lexical stress in Angelou's poem text

\begin{tabular}{|l|c|c|c|}
\hline No. & Lexical Stress & Frequency & $\%$ \\
\hline 1. & Primary stress & 43 & $93 \%$ \\
\hline 2. & Secondary stress & 3 & $7 \%$ \\
\hline \multicolumn{2}{|c|}{ Total } & 46 & 100 \\
\hline
\end{tabular}

The data above shows the primary and secondary stress found in the poem text of Angelou. The total of primary stress is forty-three of the poem texts. Then, secondary stress is only three words. It is found in each line of the stanza. The table above shows that the most extensive type of lexical stress in Angelou's poem text is primary stress with $93 \%$ or 43 words, for secondary stress with $7 \%$ or three words. Examples of lexical stress:

1) You may write me down in history.

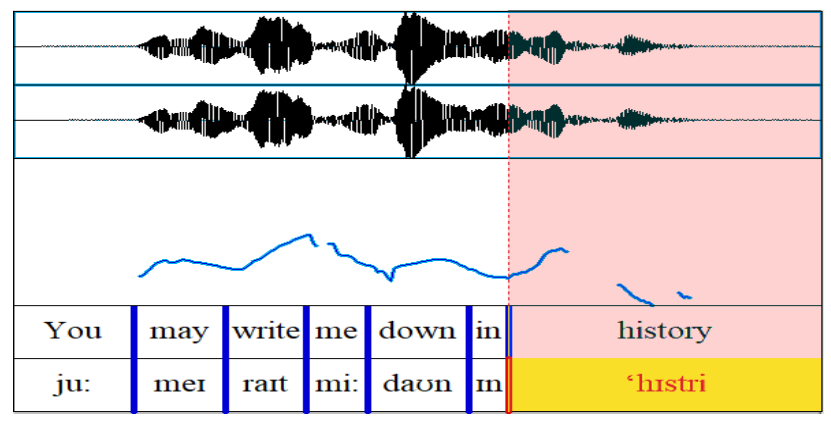

Figure 2. The stress on the word 'history'

The minimum of syllables that can be counted is two syllables. In this case, it is only one word that can be analyzed, that is, history. This word consists of two syllables is /'histri/. The phonological analysis of lexical words is seen from the phonetic symbols, not from the base word itself. So, the word history has two syllables that are /'hIs/and/tri/. In this case, the primary stress is found in the first syllable that is /'hIs/. It means that the syllable of /'hIs/ should be pronounced stronger than the syllable of tri because the primary stress is placed in the first syllable. It is supported by McMahon's theory (2002). He said that when the word is a noun, the stress falls on the first syllable. Besides, the phonological analysis of primary stress here is symbolized by apostrophe [']. 
INFERENCE: Journal of English Language Teaching

Vol. 3, No. 1, April - July 2020

p-ISSN: 2615-8671

e-ISSN: 2615-868X

2) With your bitter, twisted lies

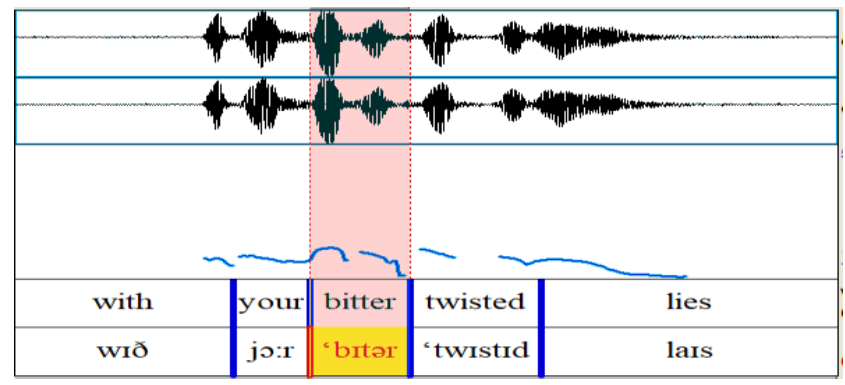

Figure 3. Bitter and Twisted

It finds two primary stresses shown in words bitter and twisted. As explained before that phonological analysis of lexical words can be counted from the phonetic symbols of words, in this case, the words "bitter" and "twisted" have two syllables that are /'bita(r)/ and /'twistid/. The word bitter has two syllables that are / $b I /$ and $/ \operatorname{ta}(r) /$. In this case, the primary stress is found in the first syllable that is $/ ' b I /$ It means that the syllable of / 'bI/ should be pronounced stronger than the syllable of $/ \mathrm{ta}(\mathrm{r}) /$ because the primary stress is placed in the first syllable. The word twisted also has two syllables that are /'twIS/ and /tId/. The syllable of / 'twIS/ should be pronounced stronger than the syllable of tId. The words "bitter" and "twisted" are classified as a noun, so the stress also falls in the first syllable.

3) You may tread me in the very dirt

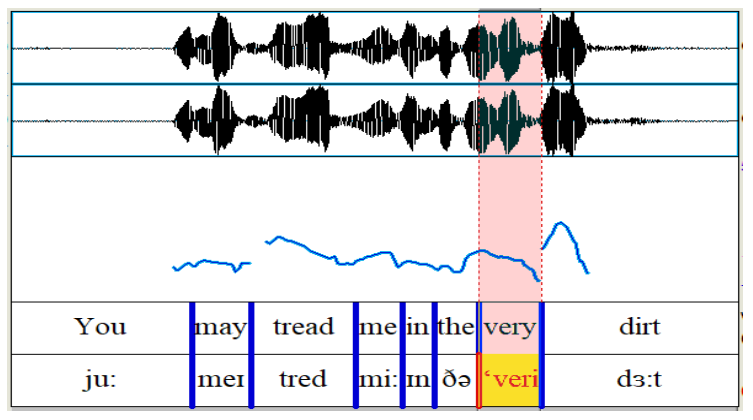

Figure 4. Stress on 'very.'

In this figure, it finds one primary stress shown in the word "very." In this case, the word very has two syllables that are /'ve/and /ri/. The primary stress is found in the first syllable that is /'ve/. It means that the syllable of /'ve/ should be pronounced stronger than the syllable of / ri/ because the primary stress is placed in the first syllable. Besides, the phonological analysis of primary stress here is symbolized by an apostrophe. The sample of lexical stress above showed by word "history, bitter, twisted and very."

\section{Metrical Stress}

The result of metrical stress showed in Table 4 below:

Table 4.

The lists of metrical stress in Angelou's poem text.

\begin{tabular}{|l|l|c|c|}
\hline No. & Metrical Stress & Frequency & $\%$ \\
\hline 1. & Iambic Foot & 9 & $21 \%$ \\
\hline 2. & Thoracic foot & 27 & $63 \%$ \\
\hline 3. & Dactylic Foot & 7 & $16 \%$ \\
\hline \multicolumn{2}{|c|}{ Total } & 43 & 100 \\
\hline
\end{tabular}


The table above shows that the most significant type of metrical stress in Angelou's poem text is Trochaic foot with $63 \%$ or finds 27 words in Angelou's poem text. Then, Iambic foot with $21 \%$ or nine words, and for Dactylic foot with $16 \%$ or seven words. Phonological analysis of metrical stress in this research is using tree diagrams. Examples of Metrical Stress:

1) History

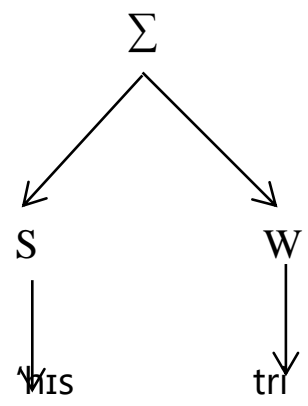

2) Bitter.

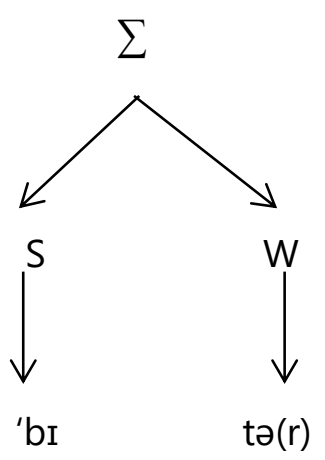

3) Twisted

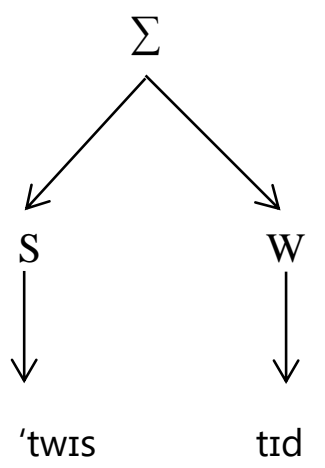

The researcher finds the same patterns in numbers (1), (2), and (3). Diagram trees of these patterns show their prominence pattern and the position of stress. This research will analyze three types of metrical stress: iambic foot, Trochaic foot, and Dactylic foot.

In this case, it is found trochee (Trochaic foot) in numbers (1), (2), and (3). These numbers indicate a trochaic foot because the syllable stars with the stronger one. It means that the syllable that gets a strong syllable has to be marked by " $\mathrm{S}$ " to indicate that the syllable is stronger than other syllables. 
INFERENCE: Journal of English Language Teaching

Vol. 3, No. 1, April - July 2020

p-ISSN: 2615-8671

e-ISSN: 2615-868X

A symbol of "S" indicates that the syllable is more potent than the other syllable in a word. Here, the trees help the reader quickly identify each word's principal stress, which will always be on the syllable dominated by nodes marked $\mathrm{S}$ up the tree.
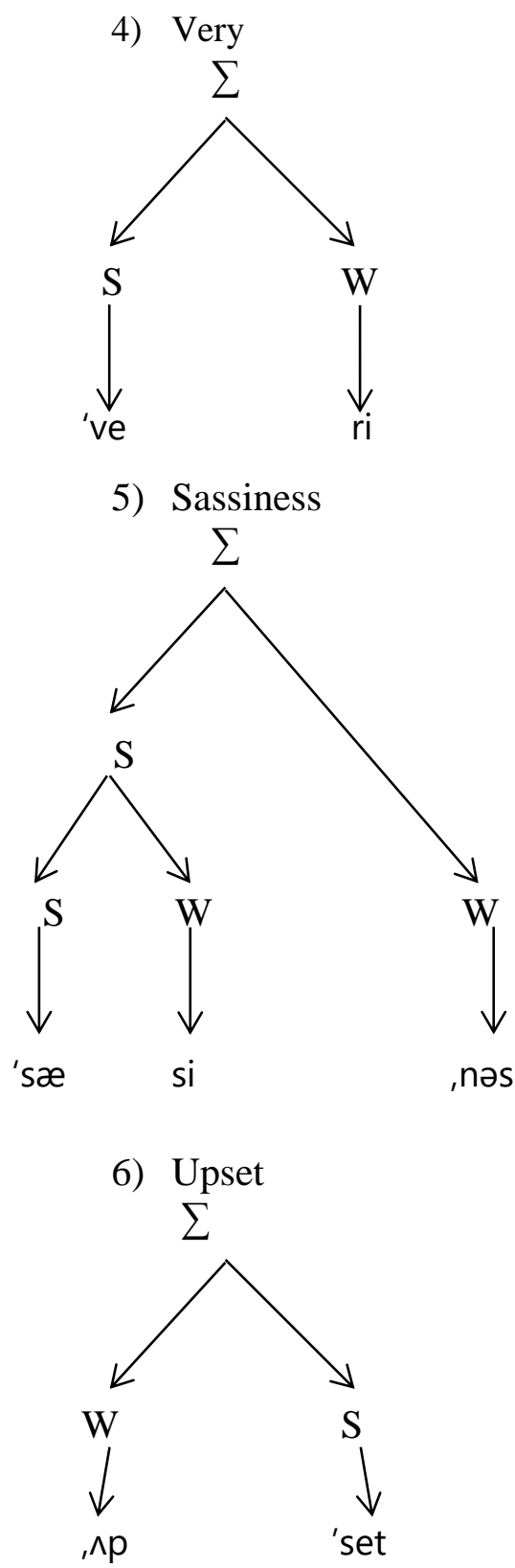

It is found different patterns in numbers (4), (5), and (6). Diagram trees of these patterns show their dominant pattern and the place of stress. In this case, its analysis three types of metrical stress are trochaic foot represented in number (4), Dactylic foot represented in number (5), and the last is Iambic foot shown in number (6). Number (4) indicates a trochaic foot because it starts with the stronger one in the first syllable, and it is 'stronger than an adjacent W.' So, it is called trochee or trochaic foot. Then, number (5) indicates as Dactylic foot because it begins to the stronger one than other syllables. It consists of three syllables where the first syllable is 'stronger than an adjacent W.' The last is number (6), which indicates Iamb or iambic foot because it starts with Weaker than other syllables. It means that this word is weaker than an adjacent $\mathrm{S}^{\prime}$. A symbol of "S" indicates that the syllable is more substantial than other syllables in a word and uses a symbol of "W" to indicate that the syllable is weaker than another syllable. Here, the trees help the reader efficiently identify the primary stress of each word. 


\section{Conclusions}

There are many lexical and metrical items in the poem text that can be analyzed in this study. Forty-three items of lexical stress represented primary stress, and three items as secondary stress. Then, metrical stress includes Iambic foot, which has nine items, Trochaic has 27 items, and Dactylic has seven items. Lexical and metrical stress plays a vital role in speaking class, especially in pronunciation. That is why the researcher analyzes the lexical and metrical stress in the poem text. Therefore, it means that lexical stress and metrical are helpful to build students' awareness of stress. They are aware of the stress and understand how to pronounce the syllable that gets prominence stress. Then, the lexical and metrical stress create the relation of meaning to build the understanding of the meaning that the speaker meant. The researcher concludes that the lexical and metrical stress can be analyzed if it consists of a minimum of two syllables in a word. The PRAAT system's software makes the reader easily understand the words analyzed in this research because it helps the readers understand the stress easily. Though, the limitation was found in this present study. The data as a unit of this analysis is not too perfect because only three secondary tress items are found in this research. Future research can explore more lexical and metrical tress, which can be found in any situation or any media.

\section{References}

Ary, D., Jacobs, L. C., Sorenson, C \& Razavieh, A. (2010). Introduction to Research Education $8^{\text {th }}$ ed. USA: Wadsworth.

Cutler, A., Dahan, D., \& van Donselaar, W. (1997). Prosody in the comprehension of spoken language: A literature review, Language and Speech. 40, 141-201

Chun, M. D. (2002). Discourse Intonation on L2 from Theory and Research Practice. Philadelphia: John Benjamin.

Creswell, W. J. (2011). Research Design Qualitative, Quantitative, and Mixed Methods Approach $3^{\text {rd }}$ $E d$. USA: Sage

Goldsmith., J., Riggle., J., \& Yu. (2011). "The Handbook of Phonological Theory, Stress System." Journal of Stress. 10.97.

Gut, U. (2009). A textbook in English Language (TELL). Introduction to English Phonetics and Phonology. New York: Peter Lang.

Hirst, D., \& Di Cristo, A. (1998). Intonation systems: A survey of twenty languages. Cambridge: Cambridge University Press.

Hopkins, D. (199). The Routledge Anthology of Poets on Poets. United Kingdom: Cambridge University Press.

Liberman, M., \& Prince, (1997). A. On stress and linguistic rhythm. Linguistic Inquiry, 8, 249-336.

Lira, O. H. (1998). Word Stress and Sentence Accent. Santiago.

McMahoon, A. (2002). An Introduction to English Phonology. Edinburgh: Edinburgh University Press.

Orion, F. G. (1976). Pronouncing American English Sound, Stress, and Intonation $2^{\text {nd }}$ Ed. Canada: Heinle.

Sa'aida, Z. A. M. (2015). Aspects of the Phonology of English Loanwords in Jordanian Urban Arabic: A Distinctive Feature, Moraic, and Metrical Stress Analysis. Jakarta.

Vendler, H. (1997). Poem, Poets, Poetry and Introduction and Anthology. Harvard: Harvard University.

Yin, R. K. (2011). Qualitative Research from Start to Finish. New York: The Guilford Press. 